TEIXEIRA JUNIOR, Vilmo Barreto. Justiça restaurativa: Uma proposta de releitura do sentido e da efetividade da resposta estatal à delinquência juvenil. Revista Eletrônica Direito e Política, Programa de Pós-Graduação Stricto Sensu em Ciência Jurídica da UNIVALI, Itajaí, v.11, n.1, $1^{\circ}$ quadrimestre de 2016. Disponível em: www.univali.br/direitoepolitica - ISSN 1980-7791.

\title{
JUSTIÇA RESTAURATIVA: UMA PROPOSTA DE RELEITURA DO SENTIDO E DA EFETIVIDADE DA RESPOSTA ESTATAL À DELINQUÊNCIA JUVENIL
}

\author{
RESTORATIVE JUSTICE: A PROPOSAL FOR A REINTERPRETETION OF \\ SENSE AND EFFECTIVENESS OF STATE RESPONSE TO JUVENILE \\ DELINQUENCY
}

Vilmo Barreto Teixeira Junior ${ }^{1}$

SUMÁRIO: Introdução; 1 Regime jurídico do ato infracional no Brasil; $1.1 \mathrm{O}$ ato infracional; 2 A problematização do paradigma retributivo no âmbito do direito da criança e do adolescente; $2.1 \mathrm{~A}$ pertinência da comparação com o direito penal; 2.2 A reincidência como sintoma do insucesso do sistema punitivo socioeducativo; 3 Justiça restaurativa; 3.1 Princípios da justiça restaurativa; 3.2 Métodos restaurativos; 4 Justiça restaurativa como meio de promoção da dignidade do adolescente; 4.1 A compatibilidade das práticas restaurativas com o ordenamento positivo; 4.2 Uma iniciativa bem-sucedida; Considerações finais.

\section{RESUMO}

O presente trabalho analisa a atual conjuntura do tratamento jurídico dispensado ao adolescente em conflito com a lei, dando um enfoque crítico nas consequências negativas da resposta à delinquência juvenil segundo o paradigma retributivo. Com marco teórico na Teoria da Justiça Restaurativa de Howard Zehr e fazendo uso do método dedutivo, o estudo tem por objetivo apresentar a justiça restaurativa como via alternativa de solução de conflitos, adaptando seus princípios de construção do reconhecimento da alteridade para a responsabilização construtiva à estrutura legal vigente. A conclusão é a de que a adoção do novo paradigma permite a construção de um sentimento efetivo de reparação no ofendido, ao mesmo tempo um de responsabilidade no adolescente, em afirmação à dignidade que os identifica na abertura do diálogo. Desse modo, a resposta estatal ao delito juvenil estaria mais próxima de alcançar sua finalidade, que é a transformação do delinquente em cidadão.

\footnotetext{
${ }^{1}$ Advogado. Pós-graduando em direito civil da Pontifícia Universidade Católica de Minas Gerais e em direito público da Universidade Fumec em Belo Horizonte. Membro do Conselho Alumni da Revista Milton Campos de Estudos Jurídicos. Belo Horizonte, Minas Gerais, Brasil. Email: vilmo.teixeirajunior@gmail.com
} 
TEIXEIRA JUNIOR, Vilmo Barreto. Justiça restaurativa: Uma proposta de releitura do sentido e da efetividade da resposta estatal à delinquência juvenil. Revista Eletrônica Direito e Política, Programa de Pós-Graduação Stricto Sensu em Ciência Jurídica da UNIVALI, Itajaí, v.11, n.1, $1^{\circ}$ quadrimestre de 2016. Disponível em: www.univali.br/direitoepolitica - ISSN 1980-7791.

PALAVRAS-CHAVE: alteridade; diálogo; responsabilidade; reparação;

ABSTRACT: This paper analyzes the current situation of the legal treatment of adolescents in conflict with the law, giving a critical focus on the negative consequences of response to juvenile delinquency according to the retributive paradigm. With theoretical framework on the Theory of Restorative Justice from Howard Zehr and using the deductive method, the study aims to present restorative justice as an alternative mean of conflict resolution, adapting its building principles of recognition of otherness for constructive accountability to the current legal structure. The conclusion is that the adoption of the new paradigm allows the construction of an effective sense of reparation to the offended at the same time a responsibility in adolescents, in affirmation of the dignity that identifies the opening of the dialogue. Thus, the state response to juvenile crime would be closer to achieve its purpose, which is the transformation of the offender in citizen.

KEYWORDS: accountability; dialogue; otherness; restorative justice; reparation;

\section{INTRODUÇÃo}

A sociedade contemporânea convive com crescentes índices de criminalidade, tendo sido observado o aumento paulatino da inserção dos adolescentes nesse fenômeno. O crescimento da delinquência faz com que a sociedade adote uma postura recrudescida em relação àqueles que violam os bens jurídicos protegidos, conduzindo a uma consolidação da intolerância.

Com isso, vê-se que os adolescentes em conflito com a lei, pessoas que ainda não têm formada por completo sua personalidade - se é que se pode falar em formação completa nessa seara - estão sujeitos precocemente à rejeição social por estarem no itinerário dos anseios populares de "justiça".

Nessa composição predisposta de conflito, a tendência é que a resposta estatal não assegure a pacificação social, pois à vítima não se garante a reparação efetiva e ao acusado não é oportunizada a compreensão do acontecimento.

É a partir desse problema que o presente trabalho aponta a justiça restaurativa como uma possível solução para a atuação efetiva no âmbito socioeducativo, 
TEIXEIRA JUNIOR, Vilmo Barreto. Justiça restaurativa: Uma proposta de releitura do sentido e da efetividade da resposta estatal à delinquência juvenil. Revista Eletrônica Direito e Política, Programa de Pós-Graduação Stricto Sensu em Ciência Jurídica da UNIVALI, Itajaí, v.11, n.1, $1^{\circ}$ quadrimestre de 2016. Disponível em: www.univali.br/direitoepolitica - ISSN 1980-7791.

pois daria ao jovem o tratamento adequado a sua condição de pessoa em desenvolvimento.

Assim, tendo como marco teórico a teoria da justiça restaurativa formulada por Howard Zehr e, fazendo uso do método dedutivo pela análise do ordenamento e de dados coletados em relatórios oficiais, o presente trabalho tem por objetivo desenvolver o tema com o rigor adequado para apresentá-lo como alternativa para solucionar esse problema social tão complexo.

$\mathrm{Na}$ primeira parte, procede-se a uma breve apresentação do atual regime jurídico do direito da criança e do adolescente com vistas a situar o ato infracional no panorama normativo vigente. Na segunda, apresenta-se uma crítica à adoção do paradigma retributivo no direito socioeducativo, indicando os prejuízos daí advindos e demonstrando por meio de dados colhidos de relatórios estatísticos a necessidade de mudança.

Na terceira parte faz-se uma apresentação da justiça restaurativa, procurando-se estudá-la a fundo para introduzi-la como uma solução própria.

Na quarta e última parte, procede-se a uma reflexão sobre a compatibilidade do proceder restaurativo com a promoção da dignidade humana, esclarecendo como o novo paradigma pode contribuir para o reconhecimento recíproco desse valor no âmbito da realidade do conflito.

\section{REGIME JURÍDICO DO ATO INFRACIONAL NO BRASIL}

O regime jurídico contemporâneo do Direito da Criança e do Adolescente resulta de um processo de evolução histórica que tem como origem o tratamento e a expansão dos direitos humanos no âmbito internacional ${ }^{2}$. Integra a trajetória do constante crescimento da abrangência do conceito de dignidade humana, como

\footnotetext{
2 Pode-se citar a Declaração de Genebra de 1924; a Declaração Universal dos Direitos Humanos das Nações Unidas de 1948; a Declaração dos direitos da Criança de 1959; Convenção Americana Sobre os Direitos Humanos, conhecido como Pacto de São José da Costa Rica de 1969; as Regras mínimas das Nações Unidas para a Administração da Justiça da Infância e da Juventude; a Convenção Sobre os Direitos da Criança de 1989.
} 
TEIXEIRA JUNIOR, Vilmo Barreto. Justiça restaurativa: Uma proposta de releitura do sentido e da efetividade da resposta estatal à delinquência juvenil. Revista Eletrônica Direito e Política, Programa de Pós-Graduação Stricto Sensu em Ciência Jurídica da UNIVALI, Itajaí, v.11, n.1, $1^{\circ}$ quadrimestre de 2016. Disponível em: www.univali.br/direitoepolitica - ISSN 1980-7791.

verdadeiro marco civilizatório no reconhecimento de uma dimensão imprescindível à sua efetividade para as crianças e adolescentes, qual seja, a condição de pessoa em desenvolvimento.

É o que se pode depreender pelos fundamentos constitucionais contidos no art. 227 da Constituição da República de 1988, que ao (re)inaugurar o ordenamento jurídico positivo, no que concerne ao direito infantojuvenil, inovou prescrevendo que $^{3}$ :

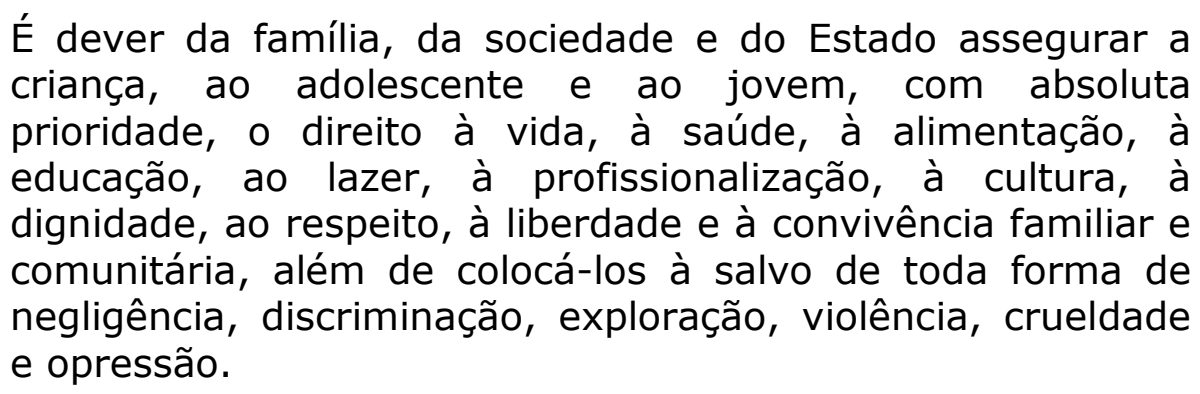

Assim, vê-se que dentro do contexto garantista da redemocratização brasileira, o constituinte e o legislador ordinário, reconhecendo a condição especial dessas pessoas em desenvolvimento, vão além das garantias constitucionais relativas aos direitos fundamentais reconhecidos segundo o paradigma da igualdade, e atribuindo a todos, família, comunidade e Estado, o dever de zelar por esses direitos quando o titular for criança ou adolescente. Diferenciou-se o tratamento por uma forma privilegiada de tutela visando à efetividade.

Nesse diapasão, conclui-se que na nova ordem - que tem como um de seus princípios a proteção integral - não só as crianças e adolescentes gozam de direitos fundamentais como qualquer pessoa, podendo exigir a observância dos mesmos como direito subjetivo, como cabe ao Poder Público e à sociedade buscar de forma constante a sua promoção.

\subsection{O ATO INFRACIONAL}

\footnotetext{
3 BRASIL. Constituição da República Federativa do Brasil. Disponível em: http://www.planalto.gov.br/ccivil_03/constituicao/ConstituicaoCompilado.htm. Acesso em: $04 / 11 / 2014$.
} 
TEIXEIRA JUNIOR, Vilmo Barreto. Justiça restaurativa: Uma proposta de releitura do sentido e da efetividade da resposta estatal à delinquência juvenil. Revista Eletrônica Direito e Política, Programa de Pós-Graduação Stricto Sensu em Ciência Jurídica da UNIVALI, Itajaí, v.11, n.1, $1^{\circ}$ quadrimestre de 2016. Disponível em: www.univali.br/direitoepolitica - ISSN 1980-7791.

A Constituição da República, coerente com o reconhecimento da situação dos jovens menores de dezoito anos como pessoas em desenvolvimento, atribuiuIhes a inimputabilidade penal em seu art. 228, deixando à legislação especial a disciplina de sua responsabilidade.

O Estatuto da Criança e do Adolescente, regulamentando a Lei Maior, definiu o ato infracional como "a conduta descrita como crime ou contravenção penal"4.

Então, pode-se dizer que apesar de não se tratar da mesma figura jurídica do crime, o ato infracional compartilha a estrutura normativa hoje adotada pela doutrina penal do conceito analítico de crime, qual seja, é a conduta típica, antijurídica e culpável. Mas é nesse último elemento que se encontra a distinção, não sendo o adolescente culpável para crime, responde pela conduta na forma da Lei 8.069/90.

Acrescenta Rossato, Lépore e Cunha5:

Mas, não basta a prática de conduta típica e antijurídica para a caracterização do ato infracional. Há necessidade, também, que os agentes somente respondam pelos atos que praticaram na medida de suas culpabilidades, uma vez que possuem capacidade valorativa e liberdade da vontade para aderir ao ilícito ou não, e com a possibilidade de terem diferentes graus de participação.

Portanto, no contexto constitucional garantista vigente, aplica-se aos atos infracionais o princípio da legalidade como balizador da análise da tipicidade ${ }^{6}$ formal e material das condutas, bem como todos os demais princípios limitadores ao direito de punir do Estado, como o da intervenção mínima, da insignificância7 e da adequação social. Ressalvando-se, apenas, a não aplicação da legalidade quanto à observância da tipicidade relativa ao preceito secundário, a

\footnotetext{
${ }^{4}$ Art. 103 da Lei 8.069/90.

5 ROSSATO, Luciano Alves, LÉPORE, Paulo Eduardo, CUNHA, Rogério Sanches, Estatuto da Criança e do Adolescente. 6a ed. São Paulo: Revista dos Tribunais, 2014.

6 Aqui trata-se de tipicidade delegada, em que busca-se a definição das condutas típicas na legislação penal comum.

7 HC 112400/RS, rel. Min. Gilmar Mendes, 22.05.2012.
} 
TEIXEIRA JUNIOR, Vilmo Barreto. Justiça restaurativa: Uma proposta de releitura do sentido e da efetividade da resposta estatal à delinquência juvenil. Revista Eletrônica Direito e Política, Programa de Pós-Graduação Stricto Sensu em Ciência Jurídica da UNIVALI, Itajaí, v.11, n.1, $1^{\circ}$ quadrimestre de 2016. Disponível em: www.univali.br/direitoepolitica - ISSN 1980-7791.

consequência do ato, que pela lei não há correspondência necessária de medida socioeducativa determinada em função do ato praticado ${ }^{8}$.

Cumpre ressaltar que há diferença fundamental no tratamento dispensado ao ato infracional praticado por criança e ao praticado por adolescente. O praticado por aquela não tem por consequência medida socioeducativa, apenas protetiva, como se verá adiante. Além disso, a apuração do ilícito praticado por criança não se dá na via judicial, pois compete ao Conselho Tutelar a aplicação das medidas protetivas pertinentes ${ }^{9}$.

\section{A PROBLEMATIZAÇÃo do PARADIgMA RETRIBUtIVO NO ÂMBITO DO DIREITO DA CRIANÇA E DO ADOLESCENTE}

O estatuto infantojuvenil atribui às medidas socioeducativas, em caráter preponderante, a finalidade educativa, buscando esvaziá-las ao máximo possível do conteúdo de castigo, tendo em vista o tratamento especial que se deve atribuir à pessoa em desenvolvimento. Entendeu o legislador que seria mais benéfico à ressocialização do jovem infrator a imposição de medida que não se apresentasse, primeiramente, como resposta de força, mas sim como orientação pedagógica compulsória.

Evidentemente a finalidade da norma serve muito mais como norte ao intérprete do que como referencial na atribuição de significado a algo imposto, por parte do jovem. Quer-se dizer que, ainda que o texto normativo tenha determinada orientação teleológica, nem sempre esse fim será assimilado pelo destinatário da norma. Principalmente levando-se em consideração as condições materiais de sua implementação.

Sendo assim, por mais que se dê preferência às medidas de meio aberto, que se limite a duração máxima dessas medidas, que se condicione sua continuidade às avaliações de aproveitamento periódicas, não se pode olvidar que o

\footnotetext{
8 Art. 112 da Lei 8.069/90.

9 Art. 136, I da Lei 8.069/90.
} 
TEIXEIRA JUNIOR, Vilmo Barreto. Justiça restaurativa: Uma proposta de releitura do sentido e da efetividade da resposta estatal à delinquência juvenil. Revista Eletrônica Direito e Política, Programa de Pós-Graduação Stricto Sensu em Ciência Jurídica da UNIVALI, Itajaí, v.11, n.1, $1^{\circ}$ quadrimestre de 2016. Disponível em: www.univali.br/direitoepolitica - ISSN 1980-7791.

procedimento que antecede a aplicação, a própria declaração de culpa que impõe a medida, e a imposição da medida em si, contêm considerável carga retributiva não só pela restrição da liberdade como consequência, mas também pelo juízo de valor negativo como pressuposto.

Pondera Afonso Armando Konzen ${ }^{10}$ :

Reside também nesse particular a principal razão para a crise da medida socioeducativa e do sistema como um todo, o que diz com o entendimento de que o procedimento de apuração do ato infracional, e a medida e consequência, possa de alguma forma justificar-se por alguma razão educativa. Confundem-se, como é do corriqueiro, as justificações para aplicação da medida com as justificações dos procederes pedagógicos do programa de atendimento que executa a medida. Nessa confusão percebe-se um duplo desrespeito. Desrespeito ao adolescente, pela pretensão de educá-lo pela punição, como se a estruturação da subjetividade pudesse ser suscetível de determinações. E Desrespeito aos contemporâneos métodos pedagógicos, pela suposição de que a pedagogia ainda bebe na fonte do medievo. [...] O dever do programa de atendimento, de exercer determinada competência pedagógica, não subtrai da medida seu capital de perda. Por melhor que seja o programa, por mais sofisticada que se apresenta a estrutura física ou os recursos humanos colocados à disposição, o adolescente continua na condição de privado ou restrito em sua liberdade.

Pode-se depreender assim, a indubitável presença do paradigma retributivo no sistema jurídico socioeducativo atual, apesar do foco pedagógico dado pela nova disciplina da execução das medidas na Lei $12.594 / 2012$, pois sempre haverá a sujeição da liberdade do adolescente como castigo, em alguma medida.

No caso da advertência, a retribuição está contida no próprio pronunciamento do agente estatal, que unilateralmente determina o desvalor da ação do infrator

10 KONZEN, Afonso Armando. Justiça Restaurativa e ato infracional: desvelando sentidos no itinerário da alteridade. Porto Alegre: Livraria do Advogado, 2007, p. 43- 48. 
TEIXEIRA JUNIOR, Vilmo Barreto. Justiça restaurativa: Uma proposta de releitura do sentido e da efetividade da resposta estatal à delinquência juvenil. Revista Eletrônica Direito e Política, Programa de Pós-Graduação Stricto Sensu em Ciência Jurídica da UNIVALI, Itajaí, v.11, n.1, $1^{\circ}$ quadrimestre de 2016. Disponível em: www.univali.br/direitoepolitica - ISSN 1980-7791.

repreendendo-o moralmente, em reafirmação da ordem jurídica anteriormente violada ${ }^{11}$.

Pode-se, num primeiro momento, questionar-se a crítica sob o argumento de que não haveria forma de solução institucionalizada que não implicasse em um mínimo de retributividade. Mas há, como se proporá adiante.

\subsection{A PERTINÊNCIA DA COMPARAÇÃO COM O DIREITO PENAL}

Desde a adoção da doutrina da proteção integral há rejeição por maior parte da doutrina de qualquer aproximação entre direito penal e direito socioeducativo. No entanto, nem toda comparação visa à afirmação de identidade ou vínculo pela semelhança, mas sim buscar elementos comuns e distintos para melhor compreensão de temas cujos objetos se sobrepõem no fenômeno da delinquência.

No particular, cumpre ressaltar que na própria estrutura do ato infracional há a presença do direito penal, não só pela tipicidade delegada, mas pela presença de todas as garantias processuais que assistem o penalmente imputável. Como anota Karyna Batista Sposato ${ }^{12}$ :

Nossa intenção, nesta etapa de estudo, é justamente demonstrar que, assim como o poder punitivo que se exerça pelos adultos imputáveis possui limitações, o mesmo ocorre em se tratando do poder de punir adolescentes. Trocando em miúdos, assim como as garantias jurídico-processuais aplicáveis aos adultos têm aplicabilidade no sistema penal juvenil, o mesmo ocorre com os princípios básicos do direito penal. Essa é uma realidade comprovável pela leitura aprofundada do que dizem a Lei 8.6069/1990 e a própria CF/1988. E no mesmo sentido estabelece o art. 152 do ECA: 'Aos procedimentos regulados nesta Lei aplicam-se subsidiariamente as normas gerais previstas na legislação processual pertinente'. [..] Nilo Batista enumera cinco

${ }^{11}$ KONZEN, Afonso Armando. Pertinência socioeducativa: reflexões sobre a natureza jurídica das medidas. Porto Alegre: Livraria do Advogado, 2005, p. 46.

12 Sposato, Karyna Batista, O Direito Penal Juvenil. São Paulo, Editora Revista dos Tribunais, 2006, p. 86. 
TEIXEIRA JUNIOR, Vilmo Barreto. Justiça restaurativa: Uma proposta de releitura do sentido e da efetividade da resposta estatal à delinquência juvenil. Revista Eletrônica Direito e Política, Programa de Pós-Graduação Stricto Sensu em Ciência Jurídica da UNIVALI, Itajaí, v.11, n.1, $1^{\circ}$ quadrimestre de 2016. Disponível em: www.univali.br/direitoepolitica - ISSN 1980-7791.

princípios penais: da legalidade ou da reserva legal, da intervenção mínima, da lesividade, da humanidade e da culpabilidade.

A semelhança, ainda que de cunho garantista, contribui para a preponderância no campo simbólico do paradigma retributivo do ponto de vista do jovem infrator. Isso porque apesar das particularidades do processo da ação socioeducativa, a estrutura do procedimento é essencialmente adversarial, com o estado acusando e julgando enquanto o adolescente se defende.

Observa Armando Konzen ${ }^{13}$ :

A decisão de aplicar a medida ao adolescente, assim como a decisão de aplicar a pena criminal ao adulto, expressa um mundo de valores em que prepondera a força, o poder, a ordem, o controle, a inflexibilidade, a segurança, o respeito ditado pela lei, valores sociais desejados pela ordem jurídica e, por isso, confiados à defesa do Estado-Juiz. No entanto, trata-se de um juízo de avaliação organizado no respeitante a um evento do passado, a respeito do que se busca uma definição: inocência e exclusão da pena, ou culpa e imposição de pena (ou inocência e exclusão de medida, ou culpa e aplicação de medida).

E nesse aspecto é que se vislumbra a relevância da comparação com o direito penal, pois é consenso na doutrina penal a adoção, na ordem atual, e a ineficácia do paradigma retributivo como referencial para a resposta estatal à delinquência.

\subsection{A REINCIDÊNCIA COMO SINTOMA DO INSUCESSO DO SISTEMA PUNITIVO SOCIOEDUCATIVO}

O objetivo do legislador ao elaborar o ordenamento positivo é incorporar os valores sociais fundamentais em um sistema normativo que contenha em si coerência suficiente para, nas sanções previstas na hipótese de violação, recompor a situação de normalidade anterior ao ilícito, em reafirmação desses axiomas. Assim, a sanção deve necessariamente conter elementos que

13 KONZEN, Afonso Armando. Justiça Restaurativa e ato infracional: desvelando sentidos no itinerário da alteridade. Porto Alegre: Livraria do Advogado, 2007, p. 63. 
TEIXEIRA JUNIOR, Vilmo Barreto. Justiça restaurativa: Uma proposta de releitura do sentido e da efetividade da resposta estatal à delinquência juvenil. Revista Eletrônica Direito e Política, Programa de Pós-Graduação Stricto Sensu em Ciência Jurídica da UNIVALI, Itajaí, v.11, n.1, $1^{\circ}$ quadrimestre de 2016. Disponível em: www.univali.br/direitoepolitica - ISSN 1980-7791.

correspondam à realidade sobre a qual incidirá conforme a finalidade da norma que a prevê, sob pena de se reafirmar a violação e não os valores protegidos.

Quando se aplica unilateralmente uma sanção que contém em si um juízo de reprovação pelo representante do Estado e da sociedade a um indivíduo que ainda está em processo de formação de sua personalidade, de sua identidade conforme os tipos sociais que Ihe são fornecidos, a consequência de tal ato, que já é incerta na pessoa adulta, se torna mais imprevisível e errática naquele que ainda está amadurecendo. Assim, ao se aplicar uma medida socioeducativa visando a ressocialização ou reorientação do jovem em conflito com a lei, podese obter um resultado diverso.

Outro não é o retrato da realidade, como se pode aferir da análise de diversos relatórios elaborados por centros regionais das varas da criança e do adolescente que apontam no sentido do alto número de delinquência entre os jovens de 15 a 17 anos, com tendências à reincidência, preponderando o tráfico de drogas como infração mais recorrente.

O Relatório estatístico 2009-2011 do CIA-BH, o Centro Integrado de Atendimento ao Adolescente Autor de Ato Infracional, descreve a situação da capital mineira, quanto à reincidência nos seguintes termos ${ }^{14}$ :

\begin{abstract}
Assim, para o ano de 2009 a taxa de atos reiterados é de $24,0 \%$ do total de 9.141 entradas; para o ano de 2010 é de $26,4 \%$ do total de 9.485 entradas e; para o ano de 2011 é de $25,8 \%$ do total de 8.842 entradas. No período de três anos, a taxa de reiteração é de $32,2 \%$ do total de 27.473 entradas. O maior número de reiteração se concentra nos atos de tráfico de drogas, uso de drogas, furto e roubo22.Com 99,0\% de confiança, há evidência de associação entre número de entradas repetidas e ato infracional cometido.
\end{abstract}

Em relatório divulgado pelo Conselho Nacional de Justiça, em pesquisa intitulada "Panorama Nacional A Execução das Medidas Socioeducativas de Internação", tem-se uma visão em âmbito nacional da reincidência ${ }^{15}$ :

\footnotetext{
14 CIA/BH - CENTRO INTEGRADO DE ATENDIMENTO AO ADOLESCENTE AUTOR DE ATO INFRACIONAL. Relatório estatístico 2009-2011. Disponível em: http://www.leffa.pro.br/textos/abnt.htm\#5.1. Acesso em: 29/10/14.
} 
TEIXEIRA JUNIOR, Vilmo Barreto. Justiça restaurativa: Uma proposta de releitura do sentido e da efetividade da resposta estatal à delinquência juvenil. Revista Eletrônica Direito e Política, Programa de Pós-Graduação Stricto Sensu em Ciência Jurídica da UNIVALI, Itajaí, v.11, n.1, $1^{\circ}$ quadrimestre de 2016. Disponível em: www.univali.br/direitoepolitica - ISSN 1980-7791.

Quanto ao aspecto da reincidência entre os adolescentes entrevistados em cumprimento de medida de internação, $43,3 \%$ já haviam sido internados ao menos uma outra vez. Deste modo, percebe-se que o índice de reincidência é significativo. Nas regiões Nordeste e Centro-Oeste, $54 \%$ e $45,7 \%$ dos jovens, respectivamente, são reincidentes; nas demais regiões 0 índice de reincidência entre os entrevistados varia entre $38,4 \%$ e $44,9 \%$.

Considerando os dados acima e o exposto no tópico anterior, é possível concluir que não se pode compatibilizar o postulado do reconhecimento da condição de pessoa em desenvolvimento com o paradigma retributivo na resposta ao delito praticado pelo adolescente, se o que se busca é a "ressocialização" efetiva.

Há de se encontrar um meio de atribuir responsabilidade de uma forma que contribua à própria formação do jovem, que não se limite à adoção de finalidades pedagógicas vazias de significado para o destinatário, mas que convide o jovem infrator a participar de forma dialógica da própria construção dessa responsabilidade para que, a compreendendo, assimile os valores envolvidos e não volte a delinquir. Essa é a proposta da Justiça Restaurativa, tema que se desenvolverá adiante.

\section{JUSTIÇA RESTAURATIVA}

Segundo Mylène Jaccoud é possível vislumbrar os traços da concepção restaurativa de justiça nas sociedades comunais pré-estatais europeias e em alguns povos nativos das américas, nos quais a transgressão das normas implicava numa mobilização de todo o grupo no sentido de restabelecer o equilíbrio rompido. Eram grupos em que a coesão social tornava intuitiva a resolução com a participação dos envolvidos e da comunidade como um todo, no

15 CNJ, DPJ e DMF. Panorama Nacional: a execução das medidas socioeducativas de internação. Disponível 
TEIXEIRA JUNIOR, Vilmo Barreto. Justiça restaurativa: Uma proposta de releitura do sentido e da efetividade da resposta estatal à delinquência juvenil. Revista Eletrônica Direito e Política, Programa de Pós-Graduação Stricto Sensu em Ciência Jurídica da UNIVALI, Itajaí, v.11, n.1, $1^{\circ}$ quadrimestre de 2016. Disponível em: www.univali.br/direitoepolitica - ISSN 1980-7791.

entanto, admitiam como sanção consequências incompatíveis com os valores restaurativos como a vingança ou a morte ${ }^{16}$.

Práticas de algumas dessas comunidades foram registradas em algumas pesquisas, dentre as quais pode-se citar a do antropólogo francês Claude LèviStrauss, que em sua obra "Tristes Trópicos", anotou a forma como a tribo brasileira Nhambiquara resolvia os conflitos entre indivíduos e grupos internos, definindo o proceder como "inspeção de reconciliação, em que o conflito cede lugar à negociação". ${ }^{17}$ Pela leitura do relato de resolução de caso que presenciou, pode-se perceber elementos da teoria restaurativa, tendo em vista que os nativos se reuniam com os envolvidos e membros da comunidade em ritual, visando o diálogo entre os participantes e os chefes comunitários para fixar a solução do conflito ${ }^{18}$.

Já nos anos 70, com a consolidação de duras críticas à perspectiva retributiva, decorrente da rejeição crescente ao reconhecimento da eficácia das penas privativas de liberdade, foram ganhando relevância as teorias alternativas de resposta ao delito. Não se podendo ignorar, também, a relevância que se atribuiu aos estudos de vitimologia, que trouxeram a vítima para o pensamento do ilícito, algo fundamental para a teoria da justiça restaurativa.

Contudo, a denominação "Justiça Restaurativa", adveio, como aponta Delano Câncio Brandão ${ }^{19}$ :

A denominação justiça restaurativa é atribuída a Albert Eglash, que, em 1977, escreveu um artigo intitulado Beyond Restitution: Creative Restitution, publicado numa obra por Joe Hudson e Burt Gallaway, denominada "Restitution in Criminal Justice". Eglash sustentou no artigo, no artigo, que havia três respostas ao crime - a retributiva, baseada na

\footnotetext{
16 JACCOUD, Mylène. Princípios, Tendências e Procedimentos que Cercam a Justiça Restaurativa. In: SLAKMON, Catherine (Org.). Justiça Restaurativa. Brasília, DF: MJ e PNUD, 2005.

17 Lèvi-Strauss, Claude. Tristes Trópicos. São Paulo: Anhembi, 1957, p. 259.

18 Lèvi-Strauss, Claude. Tristes Trópicos. São Paulo: Anhembi, 1957, p. 321-322.

19 BRANDÃO, Delano Câncio. Justiça Restaurativa no Brasil: Conceito, críticas e vantagens de um modelo alternativo de resolução de conflitos. Disponível em: http://justicarestaurativaemdebate.blospot.com.br/2010/08/artigo-justica-restaurativa-no-brasil. Acesso em: 02/11/2014.
} 
TEIXEIRA JUNIOR, Vilmo Barreto. Justiça restaurativa: Uma proposta de releitura do sentido e da efetividade da resposta estatal à delinquência juvenil. Revista Eletrônica Direito e Política, Programa de Pós-Graduação Stricto Sensu em Ciência Jurídica da UNIVALI, Itajaí, v.11, n.1, $1^{\circ}$ quadrimestre de 2016. Disponível em: www.univali.br/direitoepolitica - ISSN 1980-7791.

punição; a distributiva, focada na reeducação; e a restaurativa, cujo fundamento seria a reparação.

O interesse pelo assunto ganhou relevância internacional quando, para além das experiências exitosas no Canadá e Nova Zelândia, o Conselho Econômico e Social da ONU, reportando-se a resoluções anteriores ${ }^{20}$, editou a resolução 2002/12, de 24 de julho de 2002, propondo a adoção de práticas restaurativas a todas as práticas judiciárias, distribuindo-as por todas as fases do processo, condicionando a sua utilização ao consentimento prévio das partes, com incentivo à pesquisa e avaliação, visando à melhoria da prestação jurisdicional e ao próprio sistema de justiça ${ }^{21}$.

Mas afinal, o que vem a ser Justiça Restaurativa? Como seus principais teóricos a definem e qual é a sua proposta para tornar mais efetiva a resposta do Estado à delinquência, em especial, a delinquência infantojuvenil?

Para Howard Zehr, autor de uma das maiores obras de referência sobre Justiça Restaurativa, define ${ }^{22}$ :

A justiça restaurativa é um encontro entre as pessoas diretamente envolvidas numa situação de violência ou conflito, seus familiares, amigos e comunidades. O encontro é orientado por um coordenador e segue um roteiro prédefinido, proporcionando um espaço seguro e protegido para as pessoas abordarem o problema e construírem soluções para o futuro. A abordagem tem foco nas necessidades determinantes e emergentes do conflito, de forma a aproximar e corresponsabilizar todos os participantes com um plano de ações que visa a restaurar laços sociais e compensar danos, e a gerar compromissos de comportamentos futuros mais harmônicos. [...] A Justiça Restaurativa... 1. Tem foco nos danos e consequentes necessidades (da vítima, mas também da comunidade e do ofensor; 2. Trata das obrigações resultantes desses danos (obrigações do ofensor mas também da comunidade e da sociedade); 3 . Utiliza processos inclusivos e cooperativos; 4.

20 Em especial, as resoluções 1999/26, 2000/14 e resolução da Assembleia Geral n. 56/261.

21 ONU, CES. Resolução 2002/12 - Princípios Básicos para Utilização de Programas de Justiça Restaurativa em Matéria Criminal. Disponível em: http://justica21.org.br/j21.php?id=366\&pg=0\#.VFYcePnF_UU. Acesso em: 02/11/2014.

22 ZEHR, Howard. Trocando as Lentes: Um Novo Foco Sobre o Crime e a Justiça, Justiça Restaurativa. São Paulo: Palas Athena, 2008, p. 257. 
TEIXEIRA JUNIOR, Vilmo Barreto. Justiça restaurativa: Uma proposta de releitura do sentido e da efetividade da resposta estatal à delinquência juvenil. Revista Eletrônica Direito e Política, Programa de Pós-Graduação Stricto Sensu em Ciência Jurídica da UNIVALI, Itajaí, v.11, n.1, $1^{\circ}$ quadrimestre de 2016. Disponível em: www.univali.br/direitoepolitica - ISSN 1980-7791.

Envolve todos que tem um interesse na situação (vítimas, ofensores, a comunidade e a sociedade); 5. Busca corrigir os males.

Em estudo sobre a obra de Zehr, feito por Renato Sócrates Gomes Pinto, Justiça Restaurativa seria uma postura a ser adotada segundo o seguinte pensamento ${ }^{23}$ :

Segundo Zehr, o crime é uma infração nas relações entre o infrator, a vítima e a comunidade, cumprindo por isso, à Justiça identificar as necessidades e obrigações oriundas dessa violação e do trauma causado e que deve ser restaurado. Incumbe, assim, à Justiça oportunizar e encorajar as pessoas envolvidas a dialogarem e a chegarem a um acordo, como sujeitos centrais do processo, sendo ela, a Justiça, avaliada segundo sua capacidade de fazer com que as responsabilidades pelo cometimento do delito sejam assumidas, as necessidades oriundas da ofensa sejam satisfatoriamente atendidas e a cura, ou seja, um resultado individual e socialmente terapêutico seja alcançado.

Para Pedro Scuro e Renato Tardelli Pereira24:

[...]"fazer justiça" do ponto de vista restaurativo significa dar resposta sistemática às infrações $e$ às suas consequências, enfatizando a cura das feridas sofridas pela sensibilidade, pela dignidade ou reputação, destacando a dor, a mágoa, o dano, a ofensa, o agravo causado pelo malfeito, contando para isso com a participação de todos os envolvidos (vítima, infrator, comunidade) na resolução dos problemas (conflitos) criados por determinados incidentes. Práticas de justiça com objetivos restaurativos identificam os males infligidos e influem na sua reparação, envolvendo as pessoas e transformando suas atitudes e perspectivas em relação ao convencional sistema de Justiça, significando, assim, trabalhar para restaurar, reconstituir, construir, de sorte que, todos os envolvidos e afetados por um crime ou infração devem ter, se quiserem, a oportunidade de participar do processo restaurativo.

23 PINTO, Renato Sócrates. Justiça Restaurativa, é Possível no Brasil? In: SLAKMON, Catherine ( Org.). Justiça Restaurativa.

Disponível em: http://www.susepe.rs.gov.br/upload/1323798246_Coletania\%20JR.pdf. Acesso em: 02/11/2014.

24 SCURO, Pedro Scuro, PEREIRA, Renato Tardelli. A justiça como fator de transformação de conflitos: princípios e implementação. http://www.restorativejustice.org/10fulltext/scuro2/view. Acesso em: 02/11/14. 
TEIXEIRA JUNIOR, Vilmo Barreto. Justiça restaurativa: Uma proposta de releitura do sentido e da efetividade da resposta estatal à delinquência juvenil. Revista Eletrônica Direito e Política, Programa de Pós-Graduação Stricto Sensu em Ciência Jurídica da UNIVALI, Itajaí, v.11, n.1, $1^{\circ}$ quadrimestre de 2016. Disponível em: www.univali.br/direitoepolitica - ISSN 1980-7791.

Da formulação teórica dada pelos autores citados pode-se extrair elementos comuns que compõem os fundamentos da teoria da justiça restaurativa, dos quais é possível extrair uma síntese para elaboração de um conceito.

Tem-se como elementos comuns: a mudança da perspectiva do paradigma retributivo, centrado na fixação da culpa, para a atribuição dialógica de responsabilidade pelos danos causados; estabelecimento de procedimento diverso do acusatório, que coloca vítima e infrator em lados opostos na busca da reconstrução da "verdade" dos fatos, para adoção de um proceder cooperativo direcionado ao futuro e a identificação das necessidades geradas; não constrição subjetiva do procedimento à vítima e ofensor, mas efetiva participação de todos os afetados, inclusive pelos efeitos sociais do ilícito; o objetivo do proceder não se concentra no final juízo de culpa, tampouco na imposição do castigo, mas na descoberta do modo mais adequado para reparar os danos causados pelas consequências do delito ( do ponto de vista de todos os envolvidos).

Assim pode-se conceituar Justiça Restaurativa como uma teoria que, a partir do pressuposto de que o ilícito não é mera violação do direito, mas uma violação do relacionamento entre pessoas e dos valores de solidariedade e dignidade que 0 regem, causando sofrimento, defende um procedimento que permita a recomposição, não só dos bens jurídicos atingidos, mas do próprio vínculo intersubjetivo de solidariedade social rompido.

Pelo exposto, é possível vislumbrar os benefícios da aplicação do método restaurativo na solução do problema da delinquência infantojuvenil, levantado anteriormente. Em tese, o convite ao jovem para participar da construção de sua responsabilidade no caso concreto seria mais eficaz do que o cumprimento de programas pedagógicos que incorporam orientações ou valores que, se impostos, podem não ser reconhecidos pelo jovem como próprios.

No entanto, é de se reconhecer a complexidade de tal pretensão, que vai além da adoção de um método adequado e qualificação dos agentes da Justiça. O empreendimento deve seguir uma delicada linha, que passa pelo bom senso, pela experiência, sem se desligar dos princípios e metodologia próprios. 
TEIXEIRA JUNIOR, Vilmo Barreto. Justiça restaurativa: Uma proposta de releitura do sentido e da efetividade da resposta estatal à delinquência juvenil. Revista Eletrônica Direito e Política, Programa de Pós-Graduação Stricto Sensu em Ciência Jurídica da UNIVALI, Itajaí, v.11, n.1, $1^{\circ}$ quadrimestre de 2016. Disponível em: www.univali.br/direitoepolitica - ISSN 1980-7791.

\subsection{PRINCÍPIOS DA JUSTIÇA RESTAURATIVA}

Embora ainda sejam recentes os estudos científicos sobre a Justiça Restaurativa, importantes autores empreenderam esforços para sistematizar sua teoria com o devido rigor, e tal atividade passa necessariamente pelo estabelecimento de princípios.

Entre os autores de renome internacional Jan Froestad e Clifford Shearing, citam Crawford e Newburn, para quem os princípios fundamentais seriam três: a inclusão dos interessados, os processos deliberativos $e$ os resultados restaurativos. Van Ness e Strong, com foco no procedimento, definem quatro: encontro, reparação, reintegração e participação ${ }^{25}$.

Como a teoria da justiça restaurativa é voltada à indicação de um procedimento diferenciado para a solução de conflitos, desenvolver-se-á neste trabalho o modelo apontado, e acompanhado por outros estudiosos, de Van Ness e Strong.

Quanto ao princípio do encontro, pelo próprio pressuposto da lógica dialogal e da participação dos envolvidos, não se poderia elencar princípio mais basilar para as práticas restaurativas do que o encontro entre os envolvidos. Atendido o requisito do assentimento, pois é essencial a qualquer prática restaurativa a abertura, tanto da vítima como do ofensor, para o diálogo, deve-se promover um ambiente propício à discussão.

O encontro é o momento que marca a transição entre o passado, tempo em que ocorreu a infração, e inaugura a busca pela compreensão do ocorrido, com empenho para se desvencilhar dos estigmas do "criminoso" e da "vítima".

É importante que se forneça um espaço livre para manifestação, que gere segurança aos participantes para expressarem seus sentimentos e frustrações,

25 FROESTAD, Jim, SHEARING, Clifford. Prática da Justiça - O Modelo Zwelethemba de Resolução de Conflitos. In: SLAKMON, Catherine ( Org.). Justiça Restaurativa. Brasília, DF: MJ e PNUD, 2005. 
TEIXEIRA JUNIOR, Vilmo Barreto. Justiça restaurativa: Uma proposta de releitura do sentido e da efetividade da resposta estatal à delinquência juvenil. Revista Eletrônica Direito e Política, Programa de Pós-Graduação Stricto Sensu em Ciência Jurídica da UNIVALI, Itajaí, v.11, n.1, $1^{\circ}$ quadrimestre de 2016. Disponível em: www.univali.br/direitoepolitica - ISSN 1980-7791.

eliminando a angústia de ser um mero expectador na solução de um conflito que tanta frustração lhe causou.

Observa Eduardo Rezende Melo26:

Embora partindo de um fato situado no passado, que ditou os termos de aproximação dos participantes para a discussão, por ser o encontro o instante de avaliação, de confronto de perspectivas e de interpretações voltado ao acertamento de modos de existência e de coexistência, o eixo desloca-se ao presente com vistas ao porvir.

Quanto à participação, uma vez promovido o encontro entre os envolvidos e assegurada condições adequadas ao diálogo, deve-se dar amplo espaço e incentivar a participação livre dos envolvidos, pois são eles que, no procedimento voltado para práticas restaurativas, assumem o protagonismo da resolução da questão.

Parte da reflexão sobe o princípio perpassa a questão é, para a promoção efetiva dos objetivos restaurativos, quem deve participar?

Quanto ao infrator e à vítima, não há dúvida, pois como dito o consentimento para adoção é requisito indispensável para às práticas restaurativas e também o é a participação dos diretamente envolvidos.

O que é consenso entre os autores é a participação de um facilitador, um intermediário que conduza os encontros da forma menos impositiva possível, contribuindo para a abertura do encontro e para o estímulo à participação, podendo ser o juiz ou outro agente público com formação adequada, sob supervisão. Também é pacífico o entendimento sobre a conveniência da participação da comunidade, podendo ser entendida de modo restrito como amigos ou família dos envolvidos. No entanto, a maior parte dos autores aponta como ideal a presença de um líder comunitário, ou líderes, caso ofensor ou ofendido não compartilhem o mesmo ambiente urbano ou rural.

\footnotetext{
26 MELO, Eduardo Rezende. Justiça restaurativa e seus desafio histórico-culturais: Um ensaio crítico sobre os fundamentos ético-filosóficos da justiça restaurativa em contraposição à justiça retributiva. In: SLAKMON, Catherine ( Org.). Justiça Restaurativa. Disponível em: http://www.susepe.rs.gov.br/upload/1323798246_Coletania\%20JR.pdf. Acesso em: 02/11/14.
} 
TEIXEIRA JUNIOR, Vilmo Barreto. Justiça restaurativa: Uma proposta de releitura do sentido e da efetividade da resposta estatal à delinquência juvenil. Revista Eletrônica Direito e Política, Programa de Pós-Graduação Stricto Sensu em Ciência Jurídica da UNIVALI, Itajaí, v.11, n.1, $1^{\circ}$ quadrimestre de 2016. Disponível em: www.univali.br/direitoepolitica - ISSN 1980-7791.

Sobre a participação comunitária, Afonso Armando Konzen faz a seguinte consideração ${ }^{27}$ :

Há razões para se justificar a participação ampliada. Elena Larrauri assinala os motivos, dentre os quais o benefício ao ofendido e ao ofensor pelo despertar do sentimento de inserção em uma comunidade de cuidados, o que a presença ampliada estimula e simboliza. A presença ampliada poderia ainda, segundo a mesma autora, instituir o controle informal do respeito ao ofensor e, em consequência, a diminuição do risco da reincidência, na medida em que ser considerado poderia ser fator decisivo para a interdição da conduta violenta. Por fim, a presença ampliada poderia servir à revitalização da própria comunidade. No lugar da manutenção de um nó de discórdia, as relações afetadas pela transgressão teriam a oportunidade da pacificação.

Questões controvertidas são da participação dos advogados e do próprio Estado.

Quanto à participação do Estado há as correntes maximalistas e minimalistas. A corrente minimalista entende que por ser o modelo restaurativo diametralmente oposto ao clássico retributivo estatal, o Estado deveria dele se afastar, deixando a condução das questões a cargo de centros comunitários. Já a maximalista entende que não há incompatibilidade, e que as práticas restaurativas devem coexistir com o modelo retributivo, como um complemento, tendo em vista seu âmbito mais restrito de aplicação.

A corrente minimalista é a majoritária entre os autores, mas o que se verifica na prática, naturalmente, é a adoção da corrente maximalista.

Quanto à participação de advogados, apesar da polêmica, percebe-se que o entendimento dos especialistas aponta no sentido de que o aconselhamento jurídico pode ocorrer antes, durante a após o processo restaurativo, mas é aconselhável a participação mínima dos procuradores para se evitar o monopólio da discussão jurídica e a inversão do paradigma cooperativo para o adversarial.

Quanto ao princípio da reparação do dano, constitui o objetivo primário da justiça restaurativa. Os encontros restaurativos são direcionados à construção

27 KONZEN, Afonso Armando. Justiça Restaurativa e ato infracional: desvelando sentidos no itinerário da alteridade. Porto Alegre: Livraria do Advogado, 2007, p. 88. 
TEIXEIRA JUNIOR, Vilmo Barreto. Justiça restaurativa: Uma proposta de releitura do sentido e da efetividade da resposta estatal à delinquência juvenil. Revista Eletrônica Direito e Política, Programa de Pós-Graduação Stricto Sensu em Ciência Jurídica da UNIVALI, Itajaí, v.11, n.1, $1^{\circ}$ quadrimestre de 2016. Disponível em: www.univali.br/direitoepolitica - ISSN 1980-7791.

dialógica da responsabilidade, e ao acordo sobre qual seria a medida mais adequada a reparar o dano causado pela infração.

Porém, a reparação não se restringe à ordem patrimonial ou a qualquer outro critério pré-determinado. A estrutura comunicacional do próprio proceder restaurativo serve não só à responsabilização consciente, mas à construção do sentido daquela violação, de sua extensão, de seu simbolismo na esfera individual e comunitária, para que se encontre a reparação adequada. Podendo ela ser uma prestação pecuniária, prestação de serviços à comunidade, execução de serviço para o ofendido, ou até mesmo um pedido de desculpas.

Anotam Silvana Sandra Paz e Silvina Marcela Paz ${ }^{28}$ :

A reparação mediante o procedimento [...] pode requerer algo mais ou algo diferente da mera indenização, ou pode, em alguns casos, requerer menos para desdobrar os efeitos de atenuar ou reduzir as penas previstas em alguma condenação. Não há motivo para limitar seu conteúdo ao estritamente pecuniário, o próprio processo comunicativo desencadeado a partir de um intento de conciliação vítimaautor e os esforços que se desdobram nesse contexto com um único fim de chegar a um acordo, tendo como base o reconhecimento do fato e suas consequências, contém um potencial pacificador das relações sociais [...]

Cumpre destacar que, apesar de resultar de comum acordo, a medida reparadora deve sempre respeitar as condições do ofensor.

No que se refere ao princípio da reintegração, percebe-se que o itinerário do proceder restaurativo se inicia no encontro e visa chegar à reintegração dos envolvidos, com a comunidade e se possível, consigo mesmos pela reconciliação. Do ofendido, que abalado pela quebra de sua expectativa social de respeito e segurança, deve caminhar em direção à superação da aversão ao outro e da fragilidade moral consequente. Com o ofensor, que no caminho da superação da culpa que o procedimento restaurativo Ihe confere, não deixe para trás a responsabilidade com o cumprimento da reparação, para que possa reintegrar-se

28 Paz, Silvana Sandra, Paz, Silvina Marcela. Mediação Penal - Verdade - Justiça Restaurativa. In: SLAKMON, Catherine (Org.). Justiça Restaurativa. Disponível em: http://www.susepe.rs.gov.br/upload/1323798246_Coletania\%20JR.pdf 
TEIXEIRA JUNIOR, Vilmo Barreto. Justiça restaurativa: Uma proposta de releitura do sentido e da efetividade da resposta estatal à delinquência juvenil. Revista Eletrônica Direito e Política, Programa de Pós-Graduação Stricto Sensu em Ciência Jurídica da UNIVALI, Itajaí, v.11, n.1, $1^{\circ}$ quadrimestre de 2016. Disponível em: www.univali.br/direitoepolitica - ISSN 1980-7791.

ao meio social com a dignidade de quem compreendeu a natureza de seus atos e não se permitiu com eles se confundir.

Explica Zehr'29:

O primeiro objetivo da justiça deveria ser a reparação e cura para as vítimas. Cura para as vítimas não significa esquecer ou minimizar a violação. Implica num censo de recuperação, numa forma de fechar o ciclo. A vítima deveria voltar a sentir que a vida faz sentido e que ela está segura e no controle. O ofensor deveria ser incentivado a mudar. Ele ou ela deveriam receber a liberdade de começar a vida de novo. A cura abarca um senso de recuperação e esperança em relação ao futuro.

O princípio da reintegração pode ser entendido, nessa linha de pensamento, como o que consubstancia a finalidade do proceder, que após promover o encontro permitindo a comunicação dos envolvidos, incentivar a participação visando o entendimento, promover a reparação como forma de supressão da lembrança da violação, ao final, pode-se aferir o sucesso do trabalho, com a recuperação dos vínculos entre ofensor e ofendido, enquanto membros da sociedade.

\subsection{MÉTODOS RESTAURATIVOS}

Traçados os princípios que orientam as práticas restaurativas, levanta-se a indagação; que práticas são essas? Qual o procedimento a seguir para se alcançar tão altos objetivos como os traçados pela teoria restaurativa?

Os autores identificam, pelas experiências realizadas em países que se destacaram na realização de práticas restaurativas, como o Canadá e a Nova Zelândia, três principais formas de proceder: mediação vítima-ofensor, conferências de grupos familiares e círculos de pacificação ou de sentença.

29 ZEHR, Howard. Trocando as Lentes: Um Novo Foco Sobre o Crime e a Justiça, Justiça Restaurativa. São Paulo: Palas Athena, 2008, p. 176. 
TEIXEIRA JUNIOR, Vilmo Barreto. Justiça restaurativa: Uma proposta de releitura do sentido e da efetividade da resposta estatal à delinquência juvenil. Revista Eletrônica Direito e Política, Programa de Pós-Graduação Stricto Sensu em Ciência Jurídica da UNIVALI, Itajaí, v.11, n.1, $1^{\circ}$ quadrimestre de 2016. Disponível em: www.univali.br/direitoepolitica - ISSN 1980-7791.

Vale destacar, no entanto, que tendo a justiça restaurativa como essência a adoção de um proceder que permita a promoção de seus valores e finalidades, não se pode falar em modelos imodificáveis, certos ou errados. O que deve haver é uma adequação entre seus princípios e as etapas do procedimento eleito. 0 proceder não é determinante, mas determinado pelos valores e objetivos.

A mediação vítima-ofensor é o modelo mais adotado no mundo ${ }^{30}$ que consiste na reunião consensual entre vítima e ofensor e um mediador capacitado para promover boas condições de comunicação. Ambos os envolvidos diretos têm a oportunidade de expressar o que o ilícito significou para si, qual o sofrimento causado, o porquê da sua prática. O mediador então busca auxiliar no encontro de uma solução.

Importante ressaltar que o mediador não possui poder de decisão ou liberdade para expressar sua opinião, inclusive sendo este um ponto de distinção com os demais métodos alternativos de resolução de conflitos, como esclarece Neemias Moretti Prudente ${ }^{31}$ :

A mediação muitas vezes se combina e até se confunde com os demais meios alternativos de resolução de conflito, por existirem alguns pontos em comum, mas são modelos que apresentam algumas diferenças básicas, a saber: na negociação, não há a participação de um terceiro, as pessoas buscam, por elas mesmas, a solução do conflito (autocomposição). Na mediação se conta com a participação de um terceiro, que não tem o poder de decisão/acordo; seu papel é promover a interação e o diálogo entre as partes de modo que, cada um assuma seu papel ativo na construção de uma solução tida como justa por ambas as partes e que conduza à solução do problema. O mediador não coloca opiniões e sugestões pessoais. Na conciliação, o conciliador pode manifestar sua opinião, dar sugestões e apontar possíveis soluções para o conflito, no entanto, as partes aceitam se quiserem. Não é uma solução impositiva, e sim a opinião de uma pessoa de fora do conflito [...]. Por fim, na arbitragem, as partes escolhem um árbitro para resolver 0

\footnotetext{
30 United Nations - Office on Drugs and Crimes .Handbook On Restorative Justice Programmes. Criminal justice Handbook Series. Disponível em: http://www.unodc.org/pdf/criminal_justice/06-56290_Ebook.pdf. Acesso em 03/11/14.

31 PRUDENTE, Neemias Moretti. Justiça Restaurativa: marco teórico, experiências brasileiras, propostas e direitos humanos. Maringá: 2013 p. 143.
} 
TEIXEIRA JUNIOR, Vilmo Barreto. Justiça restaurativa: Uma proposta de releitura do sentido e da efetividade da resposta estatal à delinquência juvenil. Revista Eletrônica Direito e Política, Programa de Pós-Graduação Stricto Sensu em Ciência Jurídica da UNIVALI, Itajaí, v.11, n.1, $1^{\circ}$ quadrimestre de 2016. Disponível em: www.univali.br/direitoepolitica - ISSN 1980-7791.

conflito. O árbitro ao contrário, da mediação e da conciliação, é quem tem o poder de decisão e não as pessoas envolvidas no conflito.

Aponta-se ainda a existência da mediação nas modalidades direta e indireta. $\mathrm{Na}$ direta vítima e ofensor encontram-se presencialmente, para um contato direto. $\mathrm{Na}$ indireta, o contato é por meio de mensagens, por escrito ou em vídeo, não se permitindo o encontro físico dos envolvidos. A escolha da modalidade deve estar de acordo com a sensibilidade dos envolvidos no momento, buscando-se a aproximação em direção à modalidade direta, como meio de promover a superação das razões que dificultaram o contato inicial.

A conferência de grupos familiares é modelo de inspiração das práticas verificadas em tribos indígenas, na Nova Zelândia e no Canadá, em que há uma maior abrangência da participação. Nele incluem-se não só os envolvidos diretos, mas também os indiretos, como membros das famílias do ofensor e da vítima, amigos e membros da comunidade a que pertencem.

Tem como vantagem a colocação em perspectiva das implicações do ilícito para uma esfera que vai além das subjetividades dos indivíduos que estiveram em conflito. Permite um tratamento completo dos malefícios por ele provocado, na medida em que inclui no proceder restaurativo as pessoas que compõem os ciclos sociais a que pertencem ofendido e ofensor. Assim, fica facilitada a compreensão da extensão do dano e o modo mais adequado de repará-lo, pois pode-se contar com a contribuição daqueles que acompanharam o sofrimento dele decorrente.

Em trabalho desenvolvido pelo Ministério da Justiça Americano, mais especificamente pelo departamento de programas de justiça, baseado em pesquisa realizada por Mark Umbreit e Howard Zehr, assim define os círculos familiares ${ }^{32}$ :

\footnotetext{
32 U.S. DEPARTMENT OF JUSTICE - OFFICE OF JUSTICE PROGRAMS. Family Group Conferencing: Implications for crime victims. Disponível em: http://www.cehd.umn.edu/ssw/rjp/resources/rj_dialogue_resources/Training_Resources/Family_ Group_Conferencing.pdf. Acesso em: 03/11/2014.
} 
TEIXEIRA JUNIOR, Vilmo Barreto. Justiça restaurativa: Uma proposta de releitura do sentido e da efetividade da resposta estatal à delinquência juvenil. Revista Eletrônica Direito e Política, Programa de Pós-Graduação Stricto Sensu em Ciência Jurídica da UNIVALI, Itajaí, v.11, n.1, $1^{\circ}$ quadrimestre de 2016. Disponível em: www.univali.br/direitoepolitica - ISSN 1980-7791.

As conferências de grupos familiares envolvem a comunidade de pessoas mais afetadas pelo crime - a vítima e o ofensor e suas famílias, amigos e pessoas fundamentais que as apoiam - na decisão da solução do crime ou ato delituoso. O facilitador entra em contato com a vítima e com o ofensor para explicar o processo e convida-os para a conferência; o facilitador também pergunta a eles quem seriam as pessoas de fundamental importância em suas vidas que serão também convidadas para participar. A participação de todos é voluntária. O ofensor deve admitir a ofensa para participar. Os grupos afetados são reunidos pelo facilitador para discutir como foram feridos pela ofensa e como esse ferimento pode ser reparado (tradução nossa).

Vale destacar que a maioria dos autores recomenda cautela na adoção do modelo, que dependerá da maturidade com que os indivíduos estranhos ao fato (mas não às consequências) lidam, na ocasião, com o abalo provocado pelo delito, sob pena de se patrocinar verdadeiro retrocesso na caminhada da vítima rumo à reintegração.

Por ocasião da análise do terceiro e último modelo de proceder restaurativo aqui apresentado é possível perceber o ponto principal da diferença entre eles, que é o grau de participação da comunidade.

Nos círculos de pacificação ou círculos de pacificação de sentença vai-se além, admitindo-se a participação das famílias e grupos mais próximos, líderes comunitários e de qualquer pessoa que esteja interessada em participar, na crença de que tem algo a oferecer para a solução da questão.

Os círculos se organizam da seguinte forma: primeira etapa - verifica-se se o formato seria adequado à solução do caso, tendo em consideração o estado emocional das partes e a disposição dos pretensos participantes; segunda etapa - explica-se previamente ao ofensor e à vítima como se dará o funcionamento da dinâmica e quem participará dela; terceira etapa: procura-se um acordo consensual no círculo formado; quarta etapa: assegura-se o cumprimento do acordo alcançado ${ }^{33}$.

\footnotetext{
33 United Nations - Office on Drugs and Crimes. Handbook On Restorative Justice Programmes. Criminal justice Handbook Series. Disponível em: http://www.unodc.org/pdf/criminal_justice/06-56290_Ebook.pdf. Acesso em 03/11/14.
} 
TEIXEIRA JUNIOR, Vilmo Barreto. Justiça restaurativa: Uma proposta de releitura do sentido e da efetividade da resposta estatal à delinquência juvenil. Revista Eletrônica Direito e Política, Programa de Pós-Graduação Stricto Sensu em Ciência Jurídica da UNIVALI, Itajaí, v.11, n.1, $1^{\circ}$ quadrimestre de 2016. Disponível em: www.univali.br/direitoepolitica - ISSN 1980-7791.

A dinâmica que diferencia o proceder é a disposição ambiente dos participantes (circular), de forma que todos possam ver todos sem colocação simbólica de autoridade, proteção ou castigo. Nesse modelo aponta-se que o juiz deveria levar em consideração em sua decisão o maior número possível de elementos resultantes do proceder.

Para esse modelo, embora tenha sido adotado nos Estados Unidos em iniciativas bem-sucedidas, vale a mesma crítica do anterior, devendo o presidente da iniciativa estar atento para a pertinência positiva da participação de indivíduos que não tenham sofrido, pelo menos, as consequências remotas do delito.

\section{JUSTIÇA RESTAURATIVA COMO MEIO DE PROMOÇÃo DA DIGNIDADE DO ADOLESCENTE}

A dignidade da pessoa humana é o centro ético dos ordenamentos jurídicos ocidentais modernos. É princípio que conta com positivação constitucional na qualidade de fundamento da República, no art. $1^{\circ}$ inciso III da CR/88, garantindo a todos os direitos dele decorrentes.

A definição do conceito do que seria dignidade parte da clássica fórmula Kantiana de que o homem nunca seria um meio para alguma coisa, mas sempre um fim em si mesmo, ou seja, ao homem não se pode atribuir um valor de troca, pois o ser do gênero humano é dotado de um valor inestimável ${ }^{34}$. Os meios é que devem servi-lo, mas nunca se deve admitir que alguém se sirva de outrem, pois o outro é igualmente detentor desse valor intrínseco imensurável, que se denomina dignidade.

Ingo Wolfgang Sarlet dá a seguinte conceituação jurídica de dignidade da pessoa humana ${ }^{35}$ :

34 KANT, Immanuel. Fundamentação da metafísica dos costumes e outros escritos. São Paulo: Martin Claret, 2004 p. 46.

35 SARLET, Ingo Wolfgang. A eficácia dos direitos fundamentais na constituição federal de 1988. Porto Alegre: Livraria do Advogado, 2004, p. 59-60. 
TEIXEIRA JUNIOR, Vilmo Barreto. Justiça restaurativa: Uma proposta de releitura do sentido e da efetividade da resposta estatal à delinquência juvenil. Revista Eletrônica Direito e Política, Programa de Pós-Graduação Stricto Sensu em Ciência Jurídica da UNIVALI, Itajaí, v.11, n.1, $1^{\circ}$ quadrimestre de 2016. Disponível em: www.univali.br/direitoepolitica - ISSN 1980-7791.

[...] a qualidade intrínseca e distintiva reconhecida em cada ser humano que o faz merecedor do mesmo respeito e consideração por parte do Estado e da comunidade, implicando, neste sentido, um complexo de direitos e de deveres fundamentais que assegurem a pessoa tanto contra todo e qualquer ato de cunho degradante e desumano, como venham a lhe garantir as condições existenciais mínimas para uma vida saudável, além de propiciar e promover sua participação ativa e corresponsável nos destinos da própria existência da vida em comunhão com os demais seres humanos.

Do conceito dado pelo renomado jurista chega-se a seguinte conclusão: a efetivação da dignidade da pessoa humana perpassa necessariamente pela garantia de todos aqueles direitos reconhecidos como fundamentais, incluídos os individuais e sociais. Mas a efetivação desses direitos só poderá se dar de forma significativa no contexto das relações entre os indivíduos quando o reconhecimento dos mesmos se verifique, concomitantemente, pelo Estado e pelos próprios titulares e, entre eles, de forma recíproca.

Com isto quer-se dizer que a eficácia da dignidade como parâmetro das interações entre os indivíduos e da própria atuação do Estado está também condicionada ao mútuo reconhecimento desse valor. Seja por parte das pessoas na condição de cidadãos em conflito, como por parte daqueles que atuam na condição de agente público.

Assim, na resposta que se dá à violação de algum desses direitos, em especial à que o ordenamento atribui a natureza penal ou equivalente, não se pode ignorar esse elemento - a dignidade da pessoa humana - que dá coesão tanto ao ordenamento jurídico como ao próprio corpo social. Logo, é inconcebível uma sanção ou um procedimento que avilte o que dá integridade à dimensão relacional da sociedade. O que geraria apenas uma violação sobre violação e não reparação.

No contexto da realidade infantojuvenil a situação é ainda mais delicada, principalmente no que diz respeito à exposição do adolescente a uma ordem de perigosas relativizações de sua dignidade na dimensão comunicativa, por ocasião do cometimento do ato infracional. 
TEIXEIRA JUNIOR, Vilmo Barreto. Justiça restaurativa: Uma proposta de releitura do sentido e da efetividade da resposta estatal à delinquência juvenil. Revista Eletrônica Direito e Política, Programa de Pós-Graduação Stricto Sensu em Ciência Jurídica da UNIVALI, Itajaí, v.11, n.1, $1^{\circ}$ quadrimestre de 2016. Disponível em: www.univali.br/direitoepolitica - ISSN 1980-7791.

Por todo o procedimento de apuração e julgamento previsto em lei, percebe-se que a postura adversarial do processo o coloca em delicada situação de compreensão, em que se confunde culpa com responsabilidade, prevalecendo aquela na medida em que o foco é a reconstrução dos fatos para o juízo de culpa. E é aí que está a deficiência da atuação estatal. Ao não oportunizar à pessoa em desenvolvimento - e à vítima - o entendimento da responsabilidade pela infração à dignidade alheia, abre espaço para a equivoca interpretação pela violação da sua dignidade, ou pior, que dela não é titular.

A ausência de identificação com o elemento de integração social incentiva a inobservância das regras, pois conclui-se pela sua invalidade, em verdadeira crise de convicção da legitimidade do direito. Explica Howard Zehr ${ }^{36}$ :

Mas a um exame mais detido, vê-se que os ofensores têm dificuldades em acreditar que dessa maneira estarão de fato 'pagando sua dívida'. O 'pagamento' é demasiado abstrato e não há um reconhecimento público no final, quando dívida já foi paga. Esse pagamento não traz grande benefício para a comunidade. Aliás, custa muito dinheiro a essa mesma comunidade. Passar ao ofensor a mensagem de que 'você fez mal a alguém então nós faremos mal a você também' simplesmente aumenta a quantidade de mal neste mundo.

Logo, mostra-se mais adequada a adoção das práticas restaurativas no atendimento do adolescente, colocando-o como alguém que participa também da investigação, mas não do fato passado, mas da própria responsabilidade. Ser responsável, numa perspectiva restaurativa, significa reconhecer a própria conduta como um desvio e, consciente disso, ter a vontade de reparar o dano causado.

Permitir a participação do jovem na construção da "verdade" do caso, é permitir que ele contribua para a reparação da dignidade alheia, exercendo a própria.

36 ZEHR, Howard. Trocando as Lentes: Um Novo Foco Sobre o Crime e a Justiça, Justiça Restaurativa. São Paulo: Palas Athena, 2008, p. 72. 
TEIXEIRA JUNIOR, Vilmo Barreto. Justiça restaurativa: Uma proposta de releitura do sentido e da efetividade da resposta estatal à delinquência juvenil. Revista Eletrônica Direito e Política, Programa de Pós-Graduação Stricto Sensu em Ciência Jurídica da UNIVALI, Itajaí, v.11, n.1, $1^{\circ}$ quadrimestre de 2016. Disponível em: www.univali.br/direitoepolitica - ISSN 1980-7791.

\subsection{A COMPATIBILIDADE DAS PRÁTICAS RESTAURATIVAS COM O ORDENAMENTO POSITIVO}

As iniciativas legislativas sobre o tema além de incipientes, não estão direcionadas para o campo do direito da criança e do adolescente. O que se tem são recomendações de documentos internacionais sobre como se deve dar preferência à justiça restaurativa como complementar ao sistema penal comum.

No entanto, no campo do direito da criança e do adolescente, tem-se um panorama normativo favorável, apesar da ausência de regulamentação expressa. Isso porque a Lei 12.594/ 2012, que instituiu o SINASE e regulamentou a execução das medidas socioeducativas, elegeu como princípio, em seu art. 35 dá prioridade às práticas ou medidas restaurativas. Apesar do modelo restaurativo preponderante visar o procedimento de apuração e julgamento, a instituição como princípio da execução já é uma indicação da possível compatibilidade com o sistema legal.

O que difere no campo do direito socioeducativo que faz com que a ausência da norma regulamentadora não seja tão proibitiva quanto o é no direito penal, é o fato de não haver a já aludida correspondência necessária entre o ato infracional e determinada medida. Assim, se tem ampla possibilidade da adoção da justiça restaurativa, pois o diálogo terá a liberdade que precisa ter, ante a flexibilidade da consequência possível ao final, podendo até mesmo se admitir a remissão.

Após a oitiva do menor pelo juiz, aferindo o magistrado as condições para a realização de quaisquer métodos restaurativos, poderia optar por fazê-los ao invés de abrir prazo para defesa, sem prejuízo em caso de insucesso do empreendimento.

Poderia o Ministério Público assumir a iniciativa? Não haveria impedimento legal. No entanto, não é recomendado, pois se não houver a homologação da remissão decorrente do procedimento, poderia implicar no fracasso de futuras tentativas.

\subsection{UMA INICIATIVA BEM-SUCEDIDA}


TEIXEIRA JUNIOR, Vilmo Barreto. Justiça restaurativa: Uma proposta de releitura do sentido e da efetividade da resposta estatal à delinquência juvenil. Revista Eletrônica Direito e Política, Programa de Pós-Graduação Stricto Sensu em Ciência Jurídica da UNIVALI, Itajaí, v.11, n.1, $1^{\circ}$ quadrimestre de 2016. Disponível em: www.univali.br/direitoepolitica - ISSN 1980-7791.

Evidente que a implementação das práticas restaurativas de forma adequada é um desafio, mas quando se partem de premissas válidas dificilmente se chegará às conclusões incorretas.

É o que se verifica na análise do relatório do ano de 2012 de um dos centros de referência nacional em justiça restaurativa, o CPR/JIJ, a Central de Práticas Restaurativas do Juizado Regional da Infância e Juventude da Comarca de Porto Alegre, que informa que nos casos em que houve o pressuposto da aceitação do procedimento, o índice de construção de acordos e o respectivo cumprimento foi de $100 \%{ }^{37}$, acompanhados da melhoria dos indicadores de criminalidade juvenil. Embora indique que $37,54 \%$ do total dos casos enviados ao centro, não se chegou a realizar nenhum ato, não há prejuízo à validade da teoria, pois não restou atendido o pressuposto do consentimento dos envolvidos.

É a partir de iniciativas exitosas como essa que devem ser traçadas as diretrizes da atuação estatal para a solução da delinquência na juventude. O paradigma trazido pela teoria restaurativa atende às duas condições que se entende essenciais à atuação eficiente do Estado: coerência interna, com os princípios orientadores do ordenamento jurídico a que está submetido; e externa, com uma abordagem que considera a complexidade da realidade sobre a qual atua.

Portanto, entende-se adequada a aplicação das práticas restaurativas no âmbito socioeducativo, pois oferecem as melhores condições de se fazer valer o direito, mas não utilizando o menor como "instrumento" da reafirmação dos valores sociais vigentes, mas convidando esse especial sujeito de direitos a participar, ao lado da vítima e do Estado, dessa reafirmação. Conduzindo-se, assim, uma verdadeira caminhada rumo à conscientização da sua dignidade e a dos que o cercam.

\section{CONSIDERAÇÕES FINAIS}

37 CPR/ JIJ - CENTRAL DE PRÁTICAS RESTAURATIVAS DO JUIZADO ESPECIAL REGIONAL DA COMARCA DE PORTO ALEGRE. Ofício 014/2012 - 3a Vara do JRIJ. Disponível em: http://www.justica21.org.br/arquivos/RELATRIO+CPR+JIJ+AGO+2012+FINAL.pdf. Acesso em: 04/11/14. 
TEIXEIRA JUNIOR, Vilmo Barreto. Justiça restaurativa: Uma proposta de releitura do sentido e da efetividade da resposta estatal à delinquência juvenil. Revista Eletrônica Direito e Política, Programa de Pós-Graduação Stricto Sensu em Ciência Jurídica da UNIVALI, Itajaí, v.11, n.1, $1^{\circ}$ quadrimestre de 2016. Disponível em: www.univali.br/direitoepolitica - ISSN 1980-7791.

O direito da criança e do adolescente encontra-se hoje, no plano normativo, em nível compatível com os ditames constitucionais fundamentais.

Sob o manto da doutrina da proteção integral se reconheceu as duas condições imprescindíveis à efetivação da dignidade da pessoa humana para esses indivíduos, antes à margem do ordenamento constitucional, quais sejam, a condição de pessoa em desenvolvimento e a de sujeito de direitos. A partir daí é que se pensou em exigibilidade de políticas públicas próprias e atuação especializada por parte do Poder Público, e se passou a ter sentido a atribuição de direitos aos jovens.

São pessoas que gozam dos mesmos direitos fundamentais das pessoas capazes: vida, propriedade, saúde, educação e integridade, física e moral, principalmente no âmbito social. No entanto, até pouco tempo antes do surgimento do paradigma restaurativo de justiça se pensava - e ainda é o que se vê na prática - que para pessoas nessa condição, bastava a orientação pedagógica compulsória como consequência da prática de infração.

Acontece que tudo o que é imposto, e mais, uma imposição cuja determinação do conteúdo é totalmente subtraída daquele que a sofrerá, dificilmente atingirá qualquer finalidade pedagógica, pois é pressuposto do aprendizado a capacidade do aprendiz de responder, de reagir, e contribuir para o que the é ensinado. Tratamento diverso que pressupõe a passividade só poderá levar a incompreensão e ao não aprendizado.

Lado outro, a vítima e a sociedade são igualmente alienadas da origem dos problemas sociais dos quais decorre o crime, o que, diante de um Estado que não promove um diálogo institucionalizado com os envolvidos, a consequência só pode ser o aumento da cultura da ignorância, em que prevalece o desentendimento.

Nesse sentido, é que se apoia a adoção de práticas restaurativas. A metodologia dialogal possibilita, aos dispostos a participar, a superação da infração por meio da reparação, que nada mais é do que a medida mais adequada para a vítima se sentir recuperada do dano sofrido. E essa medida é alcançada com a participação 
TEIXEIRA JUNIOR, Vilmo Barreto. Justiça restaurativa: Uma proposta de releitura do sentido e da efetividade da resposta estatal à delinquência juvenil. Revista Eletrônica Direito e Política, Programa de Pós-Graduação Stricto Sensu em Ciência Jurídica da UNIVALI, Itajaí, v.11, n.1, $1^{\circ}$ quadrimestre de 2016. Disponível em: www.univali.br/direitoepolitica - ISSN 1980-7791.

do ofensor, que acompanhou e participou da conclusão pela sua adequação, não se sentido agredido ou prejudicado por ela, mas sim vendo-a como uma oportunidade de resgate.

Evidentemente, não se pode olvidar que a atual conjuntura cultural, resultante de anos da prevalência da moralidade do castigo e da exclusão social do delinquente, não é de molde a permitir a substituição em caráter integral do atual modelo de justiça. A sociedade não está preparada, e possivelmente nunca estará. Mas a adoção de modo complementar é impositiva. Seria inadmissível uma comunidade jurídica que adota a dignidade humana como fundamento desprezar a vontade do infrator de ser ouvido, não para o exercício adversarial da defesa, mas para expressar o sentimento de arrependimento e o ânimo de reparar o mal infligido. Ainda mais quando há disposição da vítima para tanto.

Entende-se, portanto, que a teoria da justiça restaurativa fornece um modelo válido de proceder complementar ao modelo tradicional, especialmente no âmbito socioeducativo, compatível com o tripé constitucional que atribui ao Estado, à sociedade e à família, o dever de zelar e promover os direitos dos jovens.

\section{REFERÊNCIAS DAS FONTES CITADAS}

BRASIL. Lei n 8.069 de 13 de julho de 1990. Institui o Estatuto da Criança e do Adolescente. Disponível em: <https://www.planalto.gov.br/ccivil_03/leis/L8069.htm.> Acesso em: 04 de nov. 2014.

BRASIL. Lei n 12.594 de 18 de janeiro de 2012. Institui o Sistema Nacional de Atendimento Socioeducativo (SINASE). Disponível em: <http://www.planalto.gov.br/ccivil_03/_ato2011-2014/2012/lei/l12594.htm.> Acesso em: 04 nov. 2014.

BRASIL. Constituição da República Federativa do Brasil. Disponível em: <http://www.planalto.gov.br/ccivil_03/constituicao/ConstituicaoCompilado.htm.

$>$ Acesso em: 04 nov. 2014.

BRASIL. Supremo Tribunal Federal. Acórdão que admitiu a incidência do princípio da insignificância na hipótese de ato infracional. Habeas Corpus 
TEIXEIRA JUNIOR, Vilmo Barreto. Justiça restaurativa: Uma proposta de releitura do sentido e da efetividade da resposta estatal à delinquência juvenil. Revista Eletrônica Direito e Política, Programa de Pós-Graduação Stricto Sensu em Ciência Jurídica da UNIVALI, Itajaí, v.11, n.1, $1^{\circ}$ quadrimestre de 2016. Disponível em: www.univali.br/direitoepolitica - ISSN 1980-7791.

n 112.400. Defensoria Pública da União e Superior Tribunal de Justiça. Relator: Ministro Gilmar Mendes. 8 de agosto de 2012. Disponível em: < http://stf.jusbrasil.com.br/jurisprudencia/22084873/habeas-corpus-hc-112400rs-stf/inteiro-teor-110524300>. Acesso em: 01 maio 2015.

BRANDÃO, Delano Câncio. Justiça Restaurativa no Brasil: Conceito, críticas e vantagens de um modelo alternativo de resolução de conflitos. Disponível em: <http://justicarestaurativaemdebate.blospot.com.br/2010/08/artigo-justicarestaurativa-no-brasil.> Acesso em: 02 nov.2014.

CIA/BH - CENTRO INTEGRADO DE ATENDIMENTO AO ADOLESCENTE AUTOR DE ATO INFRACIONAL. Relatório estatístico 2009-2011. Disponível em: <http://www.leffa.pro.br/textos/abnt.htm\#5.1.> Acesso em: 29 out. 2014.

CNJ, DPJ e DMF. Panorama Nacional: a execução das medidas socioeducativas de internação. Disponível em: <http://www.tjsc.jus.br/infjuv/documentos/acoeseprojetos/CNJ_panorama_naci onal_medidas_socioeducativas.pdf.> Acesso em: 29 out. 2014.

CPR/ JIJ - CENTRAL DE PRÁTICAS RESTAURATIVAS DO JUIZADO ESPECIAL REGIONAL DA COMARCA DE PORTO ALEGRE. Ofício 014/2012 - 3a Vara do JRIJ. Disponível em: <http://www.justica21.org.br/arquivos/RELATRIO+CPR+JIJ+AGO+2012+FINAL. pdf. > Acesso em: 04 nov. 2014.

FROESTAD, Jim, SHEARING, Clifford. Prática da Justiça - O Modelo Zwelethemba de Resolução de Conflitos. In: SLAKMON, Catherine (Org.). Justiça Restaurativa. Brasília, DF: MJ e PNUD, 2005.

JACCOUD, Mylène. Princípios, Tendências e Procedimentos que Cercam a Justiça Restaurativa. In: SLAKMON, Catherine (Org.). Justiça Restaurativa. Brasília, DF: MJ e PNUD, 2005.

KANT, Immanuel. Fundamentação da metafísica dos costumes e outros escritos. São Paulo: Martin Claret, 2004.

KONZEN, Afonso Armando. Justiça Restaurativa e ato infracional: desvelando sentidos no itinerário da alteridade. Porto Alegre: Livraria do Advogado, 2007.

Pertinência socioeducativa: reflexões sobre a natureza jurídica das medidas. Porto Alegre: Livraria do Advogado, 2005.

Lèvi-Strauss, Claude. Tristes Trópicos. São Paulo: Anhembi, 1957.

MELO, Eduardo Rezende. Justiça restaurativa e seus desafios histórico-culturais: Um ensaio crítico sobre os fundamentos ético-filosóficos da justiça restaurativa em contraposição à justiça retributiva. In: SLAKMON, Catherine (Org.). Justiça Restaurativa. 
TEIXEIRA JUNIOR, Vilmo Barreto. Justiça restaurativa: Uma proposta de releitura do sentido e da efetividade da resposta estatal à delinquência juvenil. Revista Eletrônica Direito e Política, Programa de Pós-Graduação Stricto Sensu em Ciência Jurídica da UNIVALI, Itajaí, v.11, n.1, $1^{\circ}$ quadrimestre de 2016. Disponível em: www.univali.br/direitoepolitica - ISSN 1980-7791.

<http://www.susepe.rs.gov.br/upload/1323798246_Coletania\%20JR.pdf>. Acesso em: 02 nov. 2014

ONU, CES. Resolução 2002/12 - Princípios Básicos para Utilização de Programas de Justiça Restaurativa em Matéria Criminal. Disponível em: <http://justica21.org.br/j21.php?id=366\&pg=0\#.VFYcePnF_UU.> Acesso em: 02 nov. 2014.

Paz, Silvana Sandra, Paz, Silvina Marcela. Mediação Penal - Verdade - Justiça Restaurativa. In: SLAKMON, Catherine (Org.). Justiça Restaurativa. Disponível em: <http://www.susepe.rs.gov.br/upload/1323798246_Coletania\%20JR.pdf>

PINTO, Renato Sócrates. Justiça Restaurativa, é Possível no Brasil? In: SLAKMON, Catherine (Org.). Justiça Restaurativa. Disponível em: <http://www.susepe.rs.gov.br/upload/1323798246_Coletania\%20JR.pdf.> Acesso em: 02 nov. 2014.

PRUDENTE, Neemias Moretti. Justiça Restaurativa: marco teórico, experiências brasileiras, propostas e direitos humanos. Maringá: 2013.

ROSSATO, Luciano Alves, LÉPORE, Paulo Eduardo, CUNHA, Rogério Sanches. Estatuto da Criança e do Adolescente. 6a ed. São Paulo: Revista dos Tribunais, 2014.

SARLET, Ingo Wolfgang. A eficácia dos direitos fundamentais na constituição federal de 1988. Porto Alegre: Livraria do Advogado, 2004.

SCURO, Pedro Scuro, PEREIRA, Renato Tardelli. A justiça como fator de transformação de conflitos: princípios e implementação. Disponível em: <http://www.restorativejustice.org/10fulltext/scuro2/view.> Acesso em: 02 nov. 2014.

SPOSATO, Karyna Batista, O Direito Penal Juvenil. São Paulo, Editora Revista dos Tribunais, 2006.

United Nations - Office on Drugs and Crimes .Handbook On Restorative Justice Programmes. Criminal justice Handbook Series. Disponível em: <http://www.unodc.org/pdf/criminal_justice/06-56290_Ebook.pdf.> Acesso em 03 nov. 2014.

U.S. DEPARTMENT OF JUSTICE - OFFICE OF JUSTICE PROGRAMS. Family Group Conferencing: Implications for crime victims. Disponível em: <http://www.cehd.umn.edu/ssw/rjp/resources/rj_dialogue_resources/Training_R esources/Family_Group_Conferencing.pdf.> Acesso em: 03 nov. 2014.

ZEHR, Howard. Trocando as Lentes: Um Novo Foco Sobre o Crime e a Justiça, Justiça Restaurativa. São Paulo: Palas Athena, 2008.

Submetido em: Agosto/2015 - Aprovado em: Março/2016 